\title{
Observations on the temperature causing mucosal damage in the dog during gastric freezing
}

\author{
J. E. LENNARD-JONES, T. SMITH, G. FARRER-BROWN,1 \\ AND R. D. PEDUZZI \\ From the Medical Research Council Gastroterenology Research Unit, \\ Central Middlesex Hospital, and the \\ Bland-Sutton Institute of Pathology, Middlesex Hospital Medical School, London.
}

EDITORIAL COMMENT This paper provides clear-cut evidence of the critical level at which mucosal necrosis occurs. It has become increasingly clear that therapeutically useful damage to secretory cells cannot be achieved without a great risk of necrosis.

'Gastric freezing' as a treatment for duodenal ulcer was introduced by Wangensteen, Peter, Nicoloff, Walder, Sosin, and Bernstein, in 1962. Since then, many patients have been treated in this way and, amongst other complications, gastric ulceration has occurred (A.M.A. Survey, 1964) and has been a cause of death. There is controversy as to the critical temperature at which mucosal damage occurs.

Experimentally, Wangensteen and his colleagues found that an inflow temperature to a gastric balloon of $-25^{\circ} \mathrm{C}$. for one hour in dogs appeared to produce no permanent damage to the gastric wall, although they did find damage soon after freezing (Allcock, Carpenter, Bernstein, Peter, and Wangensteen, 1963). McIlrath, Hallenbeck, Allen, Mann, Baldes, Brown, and Rovelstad (1963), however, observed in dogs and pigs that whenever portions of the stomach were frozen solidly, necrosis of some gastric tissue occurred. These results were supported by those of Blumgart, Kay, Naylor, and Kugler (1964) who suggested that the submucosal temperature at which ulceration occurs is between -2 and $-3 \cdot 5^{\circ} \mathrm{C}$. Gilat, Clapp, Sherlock, Creemers, Tayao, Lipkin, and Almy (1964), on the other hand, concluded from their study that no permanent damage ensued after freezing the major portion of the canine stomach for one hour. At the other extreme, Atik, Balart, Isla, and McHardy (1965) found that whenever the submucosal temperature fell to $+10^{\circ} \mathrm{C}$. or below necrosis and ulceration followed in that area.

All these studies were made using balloons over the surface of which the temperature varies (McIlrath

${ }^{1}$ Present address: Northwestern University Medical School, Chicago, Ill., U.S.A. et al., 1963; Blumgart et al., 1964) and it appeared necessary to investigate the exact temperature at which gastric damage occurs. Using a cooling disc, applied to the mucosal surface at known pressure for a constant time, we have studied in dogs the changes produced in the gastric wall over a range of surface temperatures from +2.5 to $-12.5^{\circ} \mathrm{C}$. The results indicate that destruction of mucosa is almost invariable below $-4^{\circ} \mathrm{C}$, and that deep ulceration is likely if the temperature of the serosal surface falls below $0^{\circ} \mathrm{C}$.

\section{METHOD}

The cooling applicator (Fig. 1) consisted of a hollow copper cylinder, one end of which formed the cooling disc, $2.18 \mathrm{~cm}$. in diameter, and through which alcohol was circulated at known temperature from a gastric hypothermia machine (O.E.M. model X90, Shampaine Industries). Preliminary experiments showed that the temperature was uniform over the surface of the disc. The whole surface of the applicator and the connecting tubing, except for the cooling disc, was insulated. The applicator was attached to one arm of an M.R.C. skin caliper and a copper disc of the same diameter was attached to the other arm. This device enabled a known constant pressure to be applied to the gastric wall and accurate measurements of its thickness to be made (Edwards, Hammond, Healy, Tanner, and Whitehouse, 1955). An insulated chromel-alumel thermocouple was fixed in the centre of the surface of each copper disc. Temperatures were recorded at minute intervals during each experiment using a Speedomax automatic potentiometer and recorder.

Forty-one observations were made in nine dogs, whose weight varied between 9 and $29 \mathrm{~kg}$. (Tables I and II). Under general anaesthesia, a gastrotomy, $7-8 \mathrm{~cm}$. long, 


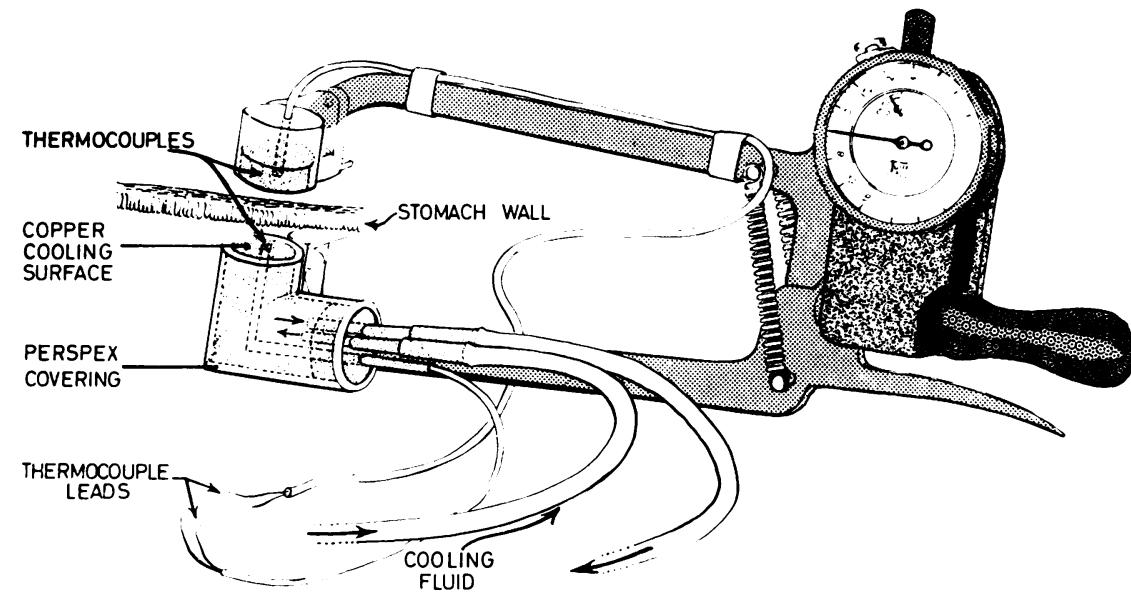

FIG. 1. Diagram of the cooling applicator.

was made. The arm of the caliper holding the applicator was inserted through the gastrotomy and the caliper closed so that an area of the gastric wall was lightly compressed between the two discs, the cooling disc being applied to the mucosal surface and the outer disc being used to apply even pressure and to hold the thermocouple against the serosal surface of the gastric wall. In 25 observations (Table I), the pressure between the discs was $142 \mathrm{~g} . / \mathrm{cm} .^{2}$ and in 16 (Table II) it was reduced to $20 \mathrm{~g} . / \mathrm{cm} .{ }^{2}$. The systolic blood pressure in the femoral

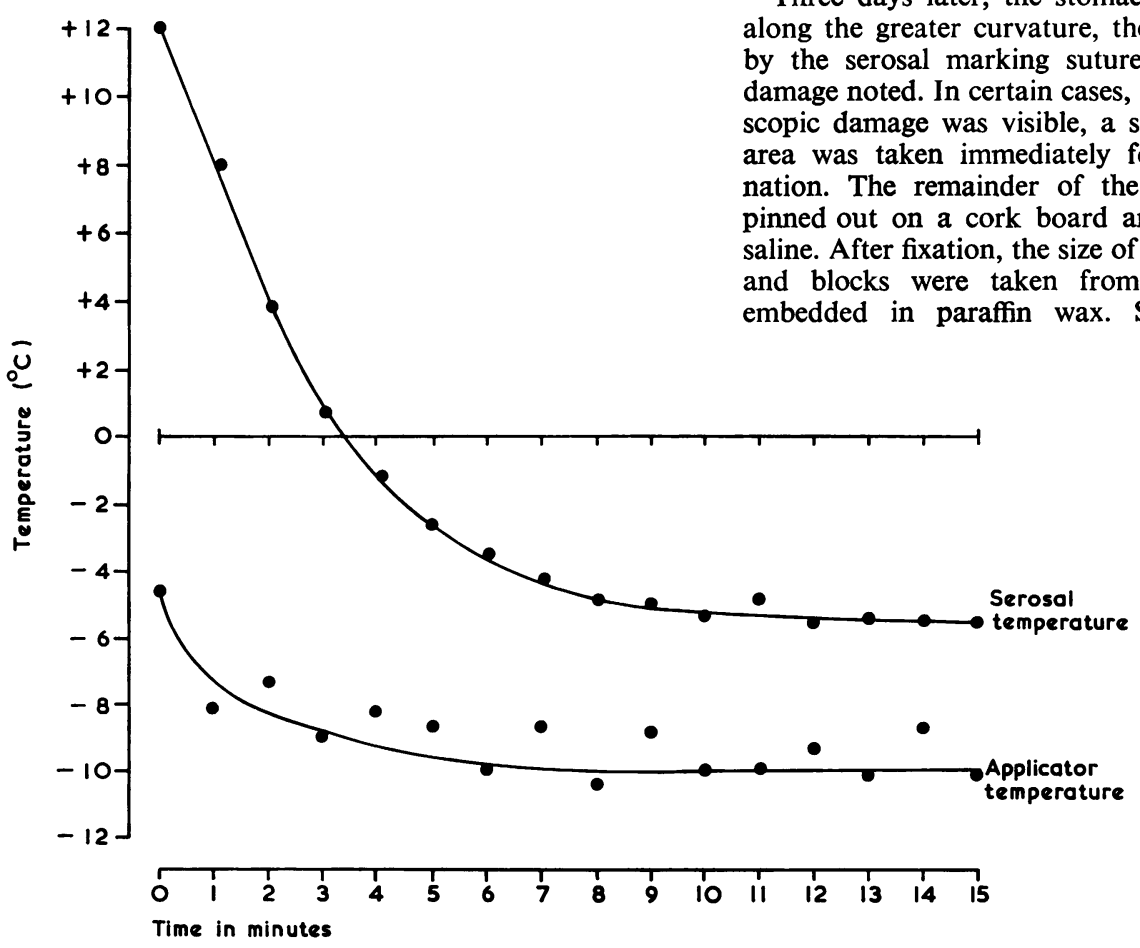

artery was measured directly with a mercury manometer when the lower pressure was used.

Cooling at a constant temperature was continued for 15 minutes. At the end of this period, the applicator was left in position until the temperature of the cooling surface had risen above $0^{\circ} \mathrm{C}$. as it was adherent to the mucosa at lower temperatures. Each area cooled was marked with serosal sutures and several areas were cooled in each dog. At the end of each experiment, the mucosal surface of each test area was examined for macroscopic changes.

Three days later, the stomach was removed, opened along the greater curvature, the cooled areas identified by the serosal marking sutures and any macroscopic damage noted. In certain cases, where little or no macroscopic damage was visible, a small part of the treated area was taken immediately for histochemical examination. The remainder of the stomach was carefully pinned out on a cork board and fixed in $10 \%$ formol saline. After fixation, the size of any ulcers was measured and blocks were taken from all cooled areas and embedded in paraffin wax. Sections were routinely

FIG. 2. Temperatures during gastric cooling: results of a representative experiment. 
stained with haematoxylin and eosin, and in certain cases additional sections were stained by the periodicacid-Schiff, Zimmerman-Marks, or Masson's trichrome methods. All histochemical studies were made on unfixed frozen sections. The calcium-cobalt method (after Gomori, see Pearse, 1960) was used for alkaline phosphatase, the standard coupling azo-dye technique (Pearse, 1960) for acid phosphatase and the method after Nachlas, Tsou, De Souza, Cheng, and Seligman (1957) using tetranitro BT. for succinic dehydrogenase.

\section{RECORDING OF RESULTS}

TEMPERATURE The temperature of the cooling disc was kept as constant as possible over each 15-minute period but fluctuations in temperature of about $1^{\circ} \mathrm{C}$. on either side of the mean value did occur. The mean temperature of the cooling disc has been used in the analysis of our results. The temperature recorded by the thermocouple applied to the serosal surface of the gastric wall tended to fall during each 15-minute period (Fig. 2) and the temperature at the end of the period, which was the lowest recorded, has been used in the analysis. The rectal temperature of each dog was recorded at intervals throughout the experiment.

GASTRIC WALL THICKNESS The thickness of the gastric wall at the site of each application was measured to the nearest $0.1 \mathrm{~mm}$. at the beginning and end of each 15 minute period using the modified M.R.C. skin calipers.

DEGREE OF DAMAGE TO THE GASTRIC WALL The macroscopic appearance of the test areas was recorded soon after cooling and at three days. Whenever severe bruising was observed soon after cooling ulceration was noted at three days. The microscopic appearances at three days, assessed without knowledge of the temperatures employed, were graded as:

(a) Mucosa normal.

(b) Surface epithelium intact but loss of parietal and peptic cells and replacement by non-specialized dilated glands lined by simple epithelium (Fig. 3).

(c) Destruction of mucosa but muscularis mucosae intact (Figure 4).

(d) Destruction of mucosa and muscularis mucosae (Figure 5).

The submucosa showed some degree of haemorrhage and oedema in every case, the muscle was normal in all cases but two (D.2 and I.6), and the serosa always showed evidence of acute inflammation.

\section{RESULTS}

The results are shown in detail in Tables $\mathbf{I}$ and II and the variables have been correlated as follows:-

CORRELATION BETWEEN APPLICATOR TEMPERATURE AND DAMAGE TO THE GASTRIC WALL Correlation was studied at two pressures.

Pressure $142 \mathrm{~g} . / \mathrm{cm}^{2}$. No macroscopic ulcer was seen at temperatures above $-4^{\circ} \mathrm{C}$. At or below this temperature an ulcer was seen in eight of 10 instances, the two areas without an ulcer being cooled at $-4{ }^{\circ} \mathrm{C}$. and $-5 \cdot 6^{\circ} \mathrm{C}$. The correlation between the microscopic appearance and the applicator temperature is shown in Figure 6. A critical level appears to exist at about $-3 \cdot 5^{\circ} \mathrm{C}$. At this temperature or above, mucosal damage was seen in only one instance (B.3) and in this case without ulceration. No histochemical changes were seen in areas which appeared normal when stained with haematoxylin and eosin. At temperatures below $-3 \cdot 5^{\circ} \mathrm{C}$. mucosal damage was seen in every case except one (E.3). The depth to which ulceration occurred depended on the applicator temperature, and below $-4{ }^{\circ} \mathrm{C}$. destruction of the mucosa and muscularis mucosae was invariable. Superficial damage to the mucosa, without destruction of the muscularis mucosae, occurred in three of the nine applications in the range -3 to $-4{ }^{\circ} \mathrm{C}$; of the remainder, five showed no damage and one ulceration involving the muscularis mucosae. Histochemical examination of one of the lesions without breach of the epithelium (B.3) showed loss of succinic dehydrogenase and acid phosphatase and alteration in the pattern of distribution of alkaline phosphatase in the treated area. No full-thickness damage to the deep muscle was seen but in one instance (D.2) severe damage of the submucosa was associated with inflammation of the adjoining muscle.

Pressure $20 \mathrm{~g} . / \mathrm{cm}^{2}$. In these experiments most of the areas were cooled to temperatures below $-3 \cdot 5^{\circ} \mathrm{C}$. and only two areas were cooled at higher temperatures. There was no damage in one of these areas (H.2) and damage to specialised glands only in the other (G.5). Macroscopic ulceration was seen in 10 of 14 areas cooled to below $-3.5^{\circ} \mathrm{C}$., the ulcers being more variable in size and shape than at the higher pressure. Ulceration was found microscopically in 12 of these 14 areas (Figure 6). Where ulceration occurred in the range -4 to $-9^{\circ} \mathrm{C}$., the muscularis mucosae remained intact at this pressure in contrast to its destruction at the higher pressure. Destruction of muscularis mucosae occurred at $-10^{\circ} \mathrm{C}$. and below. Full-thickness damage to muscle, shown by vacuolation of muscle fibres throughout, was seen in only one area, that cooled to the lowest temperature of $-12 \cdot 5^{\circ} \mathrm{C}$. (I.6).

CORRELATION BETWEEN FINAL SEROSAL TEMPERATURE AND DAMAGE TO THE GASTRIC WALL If the final serosal temperature at 15 minutes was above $0^{\circ} \mathrm{C}$. the results were variable (Fig. 7). Below $0^{\circ} \mathrm{C}$., damage to the gastric wall was invariable and below $-2^{\circ} \mathrm{C}$. the mucosa and muscularis mucosae were always destroyed. The lowest temperature of $-6 \cdot 3^{\circ} \mathrm{C}$. 


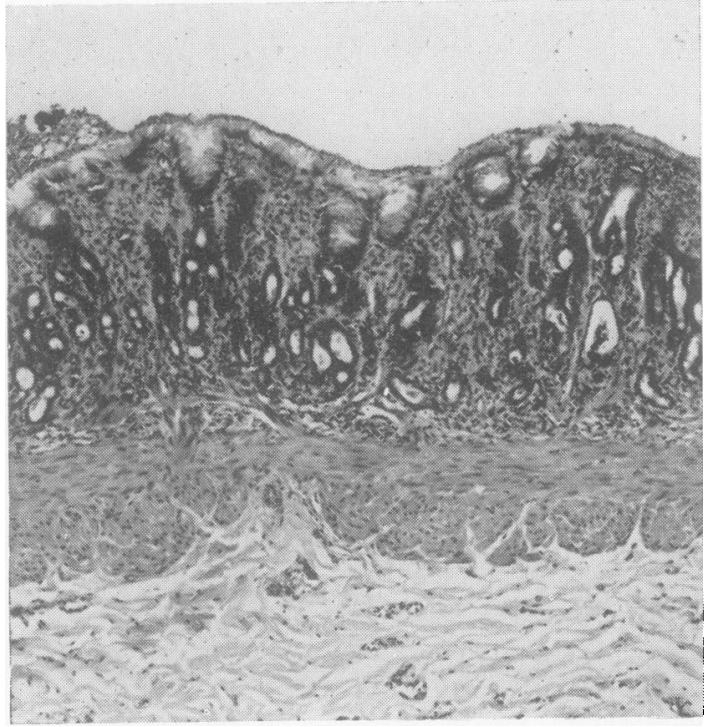

FIG. 3.

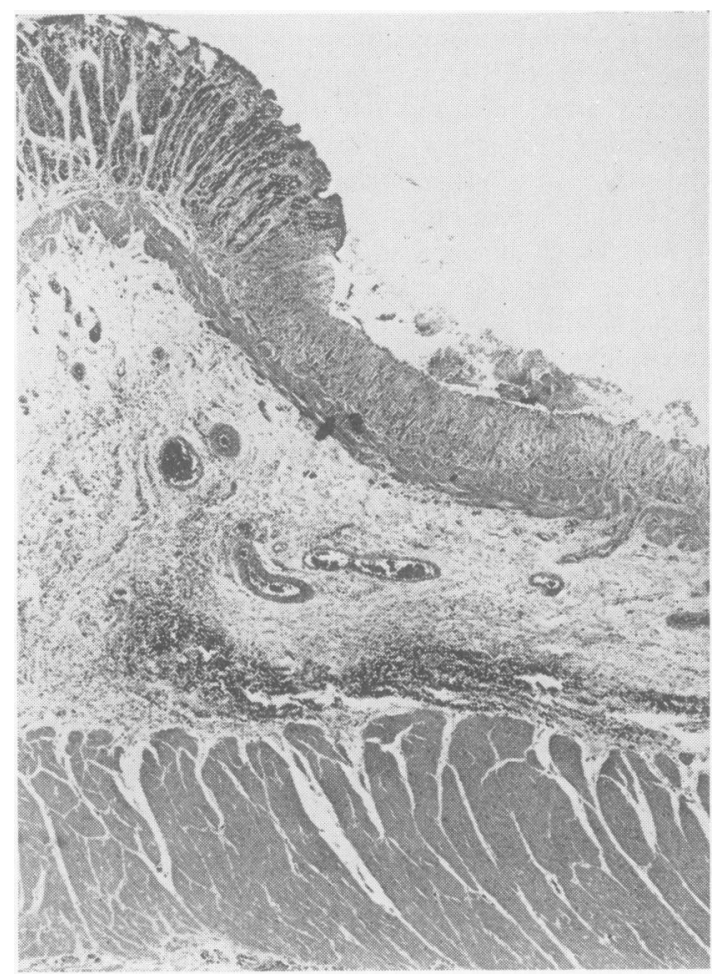

FIG. 4.

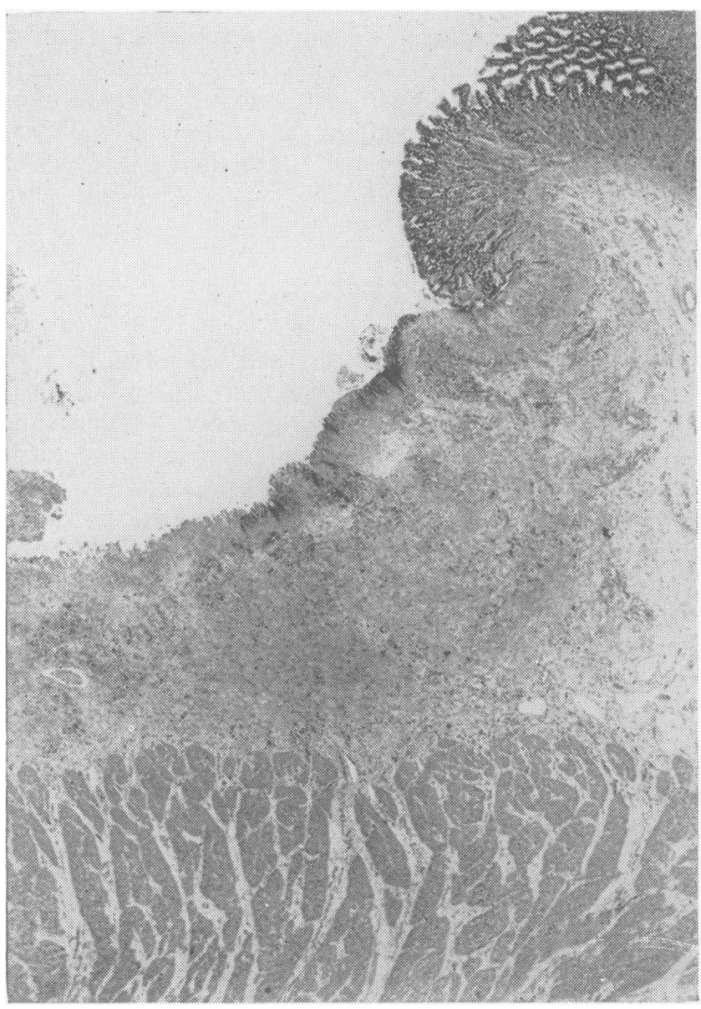

FIG. 5.

FIG. 3. Intact epithelium but loss of parietal and peptic cells and replacement by non-specialized dilated glands. Cell debris can be seen lying in the lumen of the glands (experiment B.3). Haematoxylin and eosin $\times 60$.

FIG. 4. Destruction of the mucosa, but the muscularis mucosae is intact (experiment 1.5). Haematoxylin and $\operatorname{eosin} \times 20$.

FIG. 5. Deep ulceration with destruction of the mucosa and muscularis mucosae (experiment H.5). Haematoxylin and eosin $\times 14.5$. 
TABLE I

RESULTS OF EXPERIMENTS AT A PRESSURE OF $142 \mathrm{~g} . / \mathrm{cm} .^{2}$

\begin{tabular}{|c|c|c|c|c|c|c|c|c|c|c|}
\hline \multirow{3}{*}{$\begin{array}{l}\text { Sex and } \\
\text { Weight } \\
\text { of Dogs }\end{array}$} & \multirow[t]{3}{*}{ Application } & \multicolumn{3}{|c|}{ Temperature $\left({ }^{\circ} \mathrm{C}.\right)$} & \multicolumn{2}{|c|}{$\begin{array}{l}\text { Wall Thickness } \\
(\mathrm{mm} .)\end{array}$} & \multicolumn{4}{|c|}{ Appearance of Test Areas at Three Days } \\
\hline & & \multirow{2}{*}{$\begin{array}{l}\text { Mean } \\
\text { Mucosal }\end{array}$} & \multirow{2}{*}{$\begin{array}{l}\text { Final } \\
\text { Serosal }\end{array}$} & \multirow[b]{2}{*}{ Rectal } & \multirow[b]{2}{*}{ Initial } & \multirow[b]{2}{*}{ Final } & \multirow[b]{2}{*}{ Macroscopic } & \multicolumn{3}{|l|}{ Microscopic } \\
\hline & & & & & & & & Mucosa & $\begin{array}{l}\text { Muscularis } \\
\text { Mucosae }\end{array}$ & Deep Muscle \\
\hline 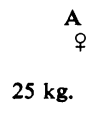 & $\begin{array}{l}1 \\
2 \\
3 \\
4\end{array}$ & $\begin{array}{l}+2.5 \\
-0.5 \\
-\quad 3.0 \\
-\quad 6.0\end{array}$ & $\begin{array}{l}+14 \\
+5.5 \\
+1.0 \\
\quad 0\end{array}$ & $\begin{array}{l}39 \cdot 7 \\
39 \cdot 1 \\
38 \cdot 5 \\
38 \cdot 1\end{array}$ & $\begin{array}{l}3 \cdot 0 \\
1 \cdot 5 \\
1 \cdot 0 \\
2 \cdot 5\end{array}$ & $\begin{array}{l}2 \cdot 0 \\
1 \cdot 2 \\
0 \cdot 7 \\
2 \cdot 3\end{array}$ & $\begin{array}{l}\text { No damage } \\
\text { No damage } \\
\text { No damage } \\
1.2 \times 0.8 \mathrm{~cm} . \text { ulcer }\end{array}$ & $\begin{array}{l}\text { Intact } \\
\text { Intact } \\
\text { Intact } \\
\text { Destroyed }\end{array}$ & $\begin{array}{l}\text { Intact } \\
\text { Intact } \\
\text { Intact } \\
\text { Destroyed }\end{array}$ & $\begin{array}{l}\text { Intact } \\
\text { Intact } \\
\text { Intact } \\
\text { Intact }\end{array}$ \\
\hline $\begin{array}{l}\text { B } \\
d\end{array}$ & $\begin{array}{l}1 \\
2 \\
3\end{array}$ & $\begin{array}{r}-5 \cdot 0 \\
-\quad 10 \cdot 0 \\
-\quad 3 \cdot 2\end{array}$ & $\begin{array}{l}+4.0 \\
-5.5 \\
-1.5\end{array}$ & $\begin{array}{l}38 \cdot 0 \\
38 \cdot 2 \\
37 \cdot 9\end{array}$ & $\begin{array}{l}2 \cdot 2 \\
2 \cdot 3 \\
0 \cdot 75\end{array}$ & $\begin{array}{l}2 \cdot 0 \\
2 \cdot 25 \\
0 \cdot 65\end{array}$ & $\begin{array}{l}0.9 \times 0.7 \mathrm{~cm} \text {. ulcer } \\
1.0 \times 1.0 \mathrm{~cm} \text {. ulcer } \\
\text { No damage }\end{array}$ & $\begin{array}{l}\text { Destroyed } \\
\text { Destroyed } \\
\text { Intact but } \\
\text { damage to } \\
\text { specialized } \\
\text { glands }\end{array}$ & $\begin{array}{l}\text { Destroyed } \\
\text { Destroyed } \\
\text { Intact }\end{array}$ & $\begin{array}{l}\text { Intact } \\
\text { Intact } \\
\text { Intact }\end{array}$ \\
\hline 25 kg. & 4 & $-7 \cdot 5$ & $-4 \cdot 5$ & $37 \cdot 6$ & $1 \cdot 7$ & $1 \cdot 65$ & $1.0 \times 1.0 \mathrm{~cm}$. ulcer & Destroyed & Destroyed & Intact \\
\hline $9 \mathrm{~kg}$. & $\begin{array}{l}1 \\
2 \\
3\end{array}$ & $\begin{array}{l}+1.5 \\
-\quad 2.3 \\
-\quad 1.5\end{array}$ & $\begin{array}{l}+5.0 \\
+1.0 \\
+3.0\end{array}$ & $\begin{array}{l}37 \cdot 5 \\
36 \cdot 5 \\
35 \cdot 5\end{array}$ & $\begin{array}{l}1 \cdot 3 \\
1 \cdot 1 \\
1 \cdot 8\end{array}$ & $\begin{array}{l}1 \cdot 0 \\
0 \cdot 6 \\
1 \cdot 0\end{array}$ & $\begin{array}{l}\text { No damage } \\
\text { No damage } \\
\text { No damage }\end{array}$ & $\begin{array}{l}\text { Intact } \\
\text { Intact } \\
\text { Intact }\end{array}$ & $\begin{array}{l}\text { Intact } \\
\text { Intact } \\
\text { Intact }\end{array}$ & $\begin{array}{l}\text { Intact } \\
\text { Intact } \\
\text { Intact }\end{array}$ \\
\hline $\mathbf{D}$ & $\begin{array}{l}1 \\
2\end{array}$ & $\begin{array}{l}-0 \cdot 7 \\
-\quad 6 \cdot 0\end{array}$ & $\begin{array}{l}+3 \cdot 5 \\
-2 \cdot 6\end{array}$ & $\begin{array}{l}36 \cdot 0 \\
36 \cdot 5\end{array}$ & $\begin{array}{l}2.0 \\
1.9\end{array}$ & $\begin{array}{l}1.4 \\
1.8\end{array}$ & $\begin{array}{l}\text { No damage } \\
1.2 \times 0.8 \mathrm{~cm} \text {. ulcer }\end{array}$ & $\begin{array}{l}\text { Intact } \\
\text { Destroyed }\end{array}$ & $\begin{array}{l}\text { Intact } \\
\text { Destroyed }\end{array}$ & $\begin{array}{l}\text { Intact } \\
\text { Intact but } \\
\text { slight damage }\end{array}$ \\
\hline $13 \mathrm{~kg}$. & $\begin{array}{l}3 \\
4\end{array}$ & $\begin{array}{l}-3 \cdot 0 \\
-\quad 3 \cdot 5\end{array}$ & $\begin{array}{l}+1 \cdot 0 \\
+2 \cdot 0\end{array}$ & $\begin{array}{l}36 \cdot 0 \\
35 \cdot 5\end{array}$ & $\begin{array}{l}2 \cdot 3 \\
2 \cdot 2\end{array}$ & $\begin{array}{l}1.6 \\
1.8\end{array}$ & $\begin{array}{l}\text { No damage } \\
\text { No damage }\end{array}$ & $\begin{array}{l}\text { Intact } \\
\text { Intact }\end{array}$ & $\begin{array}{l}\text { Intact } \\
\text { Intact }\end{array}$ & $\begin{array}{l}\text { Intact } \\
\text { Intact }\end{array}$ \\
\hline 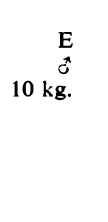 & $\begin{array}{l}1 \\
2 \\
3 \\
4 \\
5\end{array}$ & $\begin{array}{l}+\quad 0.2 \\
-\quad 3.0 \\
-\quad 5.6 \\
=\quad 0.8 \\
-\quad 4.0\end{array}$ & $\begin{array}{l}+6.3 \\
+3.4 \\
+1.3 \\
+1.8 \\
+0.8\end{array}$ & $\begin{array}{l}37 \cdot 5 \\
36 \cdot 0 \\
35 \cdot 5 \\
35 \cdot 0 \\
34 \cdot 0\end{array}$ & $\begin{array}{l}1.8 \\
1.5 \\
1.5 \\
0.9 \\
1.2\end{array}$ & $\begin{array}{l}1 \cdot 3 \\
1 \cdot 2 \\
1 \cdot 1 \\
0 \cdot 6 \\
0 \cdot 9\end{array}$ & $\begin{array}{l}\text { No damage } \\
\text { No damage } \\
\text { No damage } \\
\text { No damage } \\
\text { No damage }\end{array}$ & $\begin{array}{l}\text { Intact } \\
\text { Intact } \\
\text { Intact } \\
\text { Intact } \\
\text { Intact but } \\
\text { damage to } \\
\text { specialized } \\
\text { glands }\end{array}$ & $\begin{array}{l}\text { Intact } \\
\text { Intact } \\
\text { Intact } \\
\text { Intact } \\
\text { Intact }\end{array}$ & $\begin{array}{l}\text { Intact } \\
\text { Intact } \\
\text { Intact } \\
\text { Intact } \\
\text { Intact }\end{array}$ \\
\hline $\begin{array}{r}\mathrm{F} \\
q \\
+ \\
10 \mathrm{~kg} .\end{array}$ & $\begin{array}{l}1 \\
2 \\
3 \\
4 \\
5\end{array}$ & $\begin{array}{l}-4.8 \\
=\quad 3.8 \\
=\quad 3.2 \\
=\quad 4.0 \\
-\quad 7.6\end{array}$ & $\begin{array}{l}0 \\
+2 \cdot 7 \\
+4 \cdot 0 \\
-1 \cdot 1 \\
-5 \cdot 0\end{array}$ & $\begin{array}{l}38 \cdot 0 \\
37 \cdot 5 \\
37 \cdot 0 \\
36 \cdot 2 \\
35 \cdot 5\end{array}$ & $\begin{array}{l}1 \cdot 4 \\
2 \cdot 0 \\
1 \cdot 8 \\
1 \cdot 3 \\
1 \cdot 2\end{array}$ & $\begin{array}{l}1.4 \\
1.7 \\
1.6 \\
1.2 \\
1.2\end{array}$ & $\begin{array}{l}0.6 \times 0.6 \mathrm{~cm} \text {. ulcer } \\
\text { No damage } \\
\text { No damage } \\
0.6 \times 0.3 \mathrm{~cm} \text {. ulcer } \\
0.6 \times 0.6 \mathrm{~cm} \text {. ulcer }\end{array}$ & $\begin{array}{l}\text { Destroyed } \\
\text { Destroyed } \\
\text { Intact } \\
\text { Destroyed } \\
\text { Destroyed }\end{array}$ & $\begin{array}{l}\text { Destroyed } \\
\text { Intact } \\
\text { Intact } \\
\text { Destroyed } \\
\text { Destroyed }\end{array}$ & $\begin{array}{l}\text { Intact } \\
\text { Intact } \\
\text { Intact } \\
\text { Intact } \\
\text { Intact }\end{array}$ \\
\hline
\end{tabular}

TABLE II

RESULTS OF EXPERIMENTS AT A PRESSURE OF $20 \mathrm{~g} . / \mathrm{cm} .^{2}$

\begin{tabular}{|c|c|c|c|c|c|c|c|c|c|c|}
\hline \multirow{3}{*}{$\begin{array}{l}\text { Dog } \\
\text { Sex and } \\
\text { Weight }\end{array}$} & \multirow[t]{3}{*}{ Application } & \multicolumn{3}{|c|}{ Temperature $\left({ }^{\circ} \mathrm{C}\right)$} & \multicolumn{2}{|c|}{$\begin{array}{l}\text { Wall thickness } \\
(\mathrm{mm} .)\end{array}$} & \multicolumn{4}{|c|}{ Appearance of test areas at three days } \\
\hline & & \multirow{2}{*}{$\begin{array}{l}\text { Mean } \\
\text { Mucosal }\end{array}$} & \multirow{2}{*}{$\begin{array}{l}\text { Final } \\
\text { Serosal }\end{array}$} & \multirow[b]{2}{*}{ Rectal } & \multirow[b]{2}{*}{ Initial } & \multirow[b]{2}{*}{ Final } & \multirow[b]{2}{*}{ Macroscopic } & \multicolumn{3}{|l|}{ Microscopic } \\
\hline & & & & & & & & Mucosa & $\begin{array}{l}\text { Muscularis } \\
\text { Mucosae }\end{array}$ & Deep Muscle \\
\hline $\begin{array}{c}\mathrm{G} \\
\stackrel{+}{+} \\
15 \cdot 5 \mathrm{~kg} .\end{array}$ & $\begin{array}{l}1 \\
2 \\
3 \\
4 \\
5\end{array}$ & $\begin{array}{l}-5.5 \\
-\quad 5.0 \\
-\quad 10.0 \\
-\quad 7.0 \\
-\quad 2.8\end{array}$ & $\begin{array}{l}+2.3 \\
+13.6 \\
-\quad 1.5 \\
+13.5 \\
+\quad 8.5\end{array}$ & $\begin{array}{l}38 \cdot 0 \\
38 \cdot 0 \\
37 \cdot 5 \\
37 \cdot 5 \\
37 \cdot 0\end{array}$ & $\begin{array}{l}2 \cdot 3 \\
3 \cdot 1 \\
3 \cdot 5 \\
4 \cdot 8 \\
1 \cdot 8\end{array}$ & $\begin{array}{l}2 \cdot 2 \\
2 \cdot 1 \\
3 \cdot 7 \\
4 \cdot 6 \\
1 \cdot 6\end{array}$ & $\begin{array}{l}\text { No damage } \\
30.3 \times 0.2 \mathrm{~cm} \text {. ulcer } \\
2.5 \times 1.0 \mathrm{~cm} \text {. ulcer } \\
\text { No damage } \\
\text { No damage }\end{array}$ & $\begin{array}{l}\text { Intact } \\
\text { Destroyed } \\
\text { Destroyed } \\
\text { Destroyed } \\
\text { Intact but } \\
\text { damage to } \\
\text { specialized } \\
\text { glands }\end{array}$ & $\begin{array}{l}\text { Intact } \\
\text { Intact } \\
\text { Destroyed } \\
\text { Intact } \\
\text { Intact }\end{array}$ & $\begin{array}{l}\text { Intact } \\
\text { Intact } \\
\text { Intact } \\
\text { Intact } \\
\text { Intact }\end{array}$ \\
\hline $\begin{array}{r}H \\
\stackrel{+}{+} \\
19 \cdot 2 \mathrm{~kg} .\end{array}$ & $\begin{array}{l}1 \\
2 \\
3 \\
4 \\
5\end{array}$ & $\begin{array}{r}-4.0 \\
-\quad 2.8 \\
-\quad 6.5 \\
-\quad 9.0 \\
-11.5\end{array}$ & $\begin{array}{l}+13.5 \\
+15.0 \\
+16.5 \\
+\quad 1.7 \\
-\quad 4.5\end{array}$ & $\begin{array}{l}39 \cdot 0 \\
38 \cdot 5 \\
38 \cdot 5 \\
38 \cdot 0 \\
38 \cdot 0\end{array}$ & $\begin{array}{l}2 \cdot 7 \\
3 \cdot 6 \\
5 \cdot 3 \\
4 \cdot 2 \\
2 \cdot 6\end{array}$ & $\begin{array}{l}2 \cdot 5 \\
3 \cdot 0 \\
4 \cdot 7 \\
4 \cdot 3 \\
2 \cdot 8\end{array}$ & $\begin{array}{l}\text { No damage } \\
\text { No damage } \\
\text { No damage } \\
1.0 \times 0.6 \mathrm{~cm} \text {. ulcer } \\
1.0 \times 1.0 \mathrm{~cm} \text {. ulcer }\end{array}$ & $\begin{array}{l}\text { Intact } \\
\text { Intact } \\
\text { Destroyed } \\
\text { Destroyed } \\
\text { Destroyed }\end{array}$ & $\begin{array}{l}\text { Intact } \\
\text { Intact } \\
\text { Intact } \\
\text { Destroyed } \\
\text { Destroyed }\end{array}$ & $\begin{array}{l}\text { Intact } \\
\text { Intact } \\
\text { Intact } \\
\text { Intact } \\
\text { Intact }\end{array}$ \\
\hline $29 \mathrm{~kg}$. & $\begin{array}{l}1 \\
2 \\
3 \\
4 \\
5 \\
6\end{array}$ & $\begin{array}{l}-\quad 5 \cdot 3 \\
-\quad 9 \cdot 2 \\
-\quad 8 \cdot 7 \\
-\quad 7 \cdot 2 \\
-\quad 4 \cdot 0 \\
-12 \cdot 5\end{array}$ & $\begin{array}{l}+17.0 \\
+10.6 \\
+\quad 1.0 \\
+10.0 \\
+\quad 0.6 \\
-\quad 6.3\end{array}$ & $\begin{array}{l}39 \cdot 0 \\
38 \cdot 5 \\
38 \cdot 5 \\
38 \cdot 5 \\
38 \cdot 1 \\
38 \cdot 0\end{array}$ & $\begin{array}{l}4 \cdot 0 \\
5 \cdot 2 \\
4 \cdot 3 \\
4 \cdot 7 \\
2 \cdot 5 \\
2 \cdot 7\end{array}$ & $\begin{array}{l}3 \cdot 3 \\
5 \cdot 0 \\
3 \cdot 4 \\
4 \cdot 0 \\
2 \cdot 4 \\
2 \cdot 3\end{array}$ & $\begin{array}{l}1.0 \times 1.0 \mathrm{~cm} \text {. ulcer } \\
1.2 \times 0.3 \mathrm{~cm} \text {. ulcer } \\
1.0 \times 0.5 \mathrm{~cm} \text {. ulcer } \\
0.4 \times 0.2 \mathrm{~cm} \text {. ulcer } \\
1.2 \times 0.8 \mathrm{~cm} \text {. ulcer } \\
1.2 \times 1.0 \mathrm{~cm} \text {. ulcer }\end{array}$ & $\begin{array}{l}\text { Destroyed } \\
\text { Destroyed } \\
\text { Destroyed } \\
\text { Destroyed } \\
\text { Destroyed } \\
\text { Destroyed }\end{array}$ & $\begin{array}{l}\text { Intact } \\
\text { Intact } \\
\text { Intact } \\
\text { Intact } \\
\text { Intact } \\
\text { Destroyed }\end{array}$ & $\begin{array}{l}\text { Intact } \\
\text { Intact } \\
\text { Intact } \\
\text { Intact } \\
\text { Intact } \\
\text { Vacuolation of } \\
\text { fibres }\end{array}$ \\
\hline
\end{tabular}




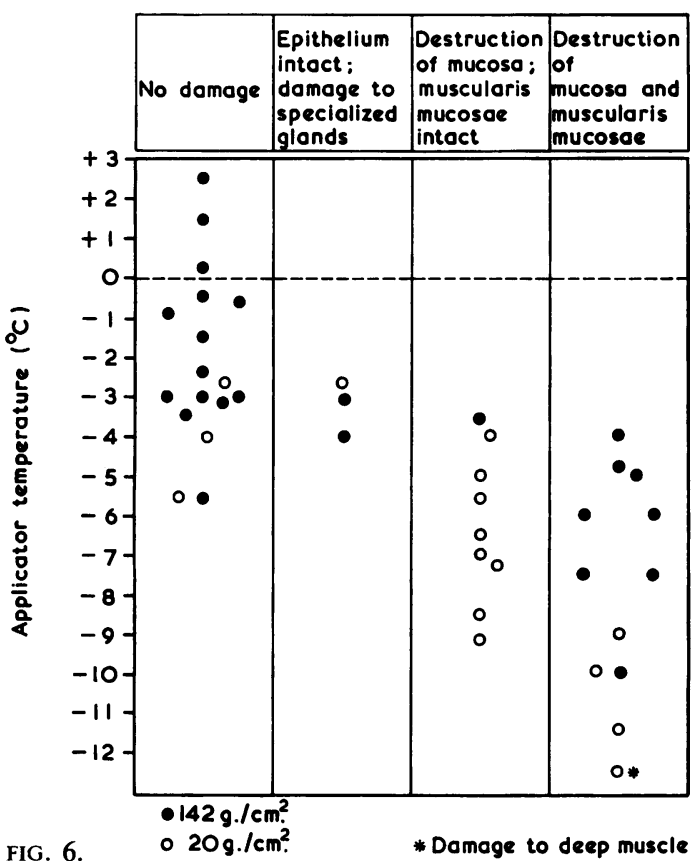

FIG. 6. Correlation of mucosal damage with surface temperature of applicator.

FIG. 7. Correlation of mucosal damage with final serosal temperature.

(I·6) was associated with full-thickness muscle damage.

CORRELATIONS WITH GASTRIC WALL THICKNESS No useful information was obtained by measuring gastric wall thickness. As expected, the thickness tended to be greater with the lower of the two pressures used. There was no obvious correlation between gastric wall damage, or between the temperature differential across the gastric wall, and thickness.

OTHER MEASUREMENTS The rectal temperature fell in every dog during the experiment, the maximum fall being $3.5^{\circ} \mathrm{C}$. The systolic blood pressure was measured in the last three dogs and varied between 120 and $170 \mathrm{~mm} . \mathrm{Hg}$.

\section{COMMENT}

These experiments were designed to study structural changes in the gastric wall after cooling under controlled conditions. At open operation, areas of the gastric wall were cooled by a standard disc

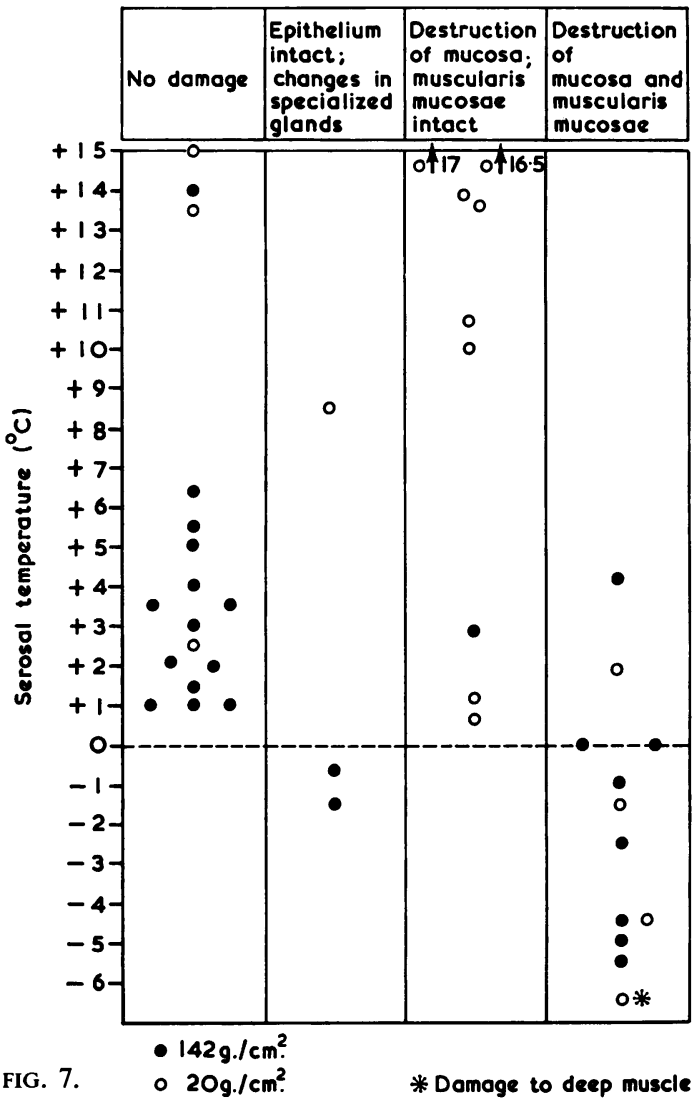

applied at selected temperatures for a constant time and at known pressure. The observations were made in dogs because of the anatomical similarities between the stomach of this animal and of man. A three-day interval after cooling was found to be a satisfactory time at which to assess damage but no study has been made of the rate and completeness of healing, though it was noted that regenerating tubules were present at the edge of all ulcers. The two pressures employed were equivalent to 105 and $15 \mathrm{~mm} . \mathrm{Hg}$, the lower pressure being chosen to exclude any effect of the higher pressure on blood flow.

The conclusions possible from the results are limited by the particular conditions of the experiment, but some generalizations seem justifiable. Damage to the gastric wall is unlikely if a cooling surface at a temperature above $-3^{\circ} \mathrm{C}$. is applied to the mucosa for 15 minutes. In the range -2 to $-4^{\circ} \mathrm{C}$. damage to specialized cells can be produced without ulceration, though the damage is inconstant and uniform cooling within this narrow range is unlikely to be achieved in clinical practice. If the gastric wall is subjected to a temperature below 
$-4^{\circ} \mathrm{C}$. for 15 minutes the mucosa is destroyed. This agrees with the finding of Blumgart et al. (1964) that ulceration occurs at a submucosal temperature between -2 and $-3.5^{\circ} \mathrm{C}$. and may be compared with the temperature of $-2^{\circ} \mathrm{C}$. found to be the freezing point of gastric mucosa in vitro (McSweeney, Melnyk, Deshpande, Benson, and Jacob, 1963). Between -4 and $-9^{\circ} \mathrm{C}$., the muscularis mucosae may be preserved by applying the cold surface at a low pressure. Destruction of this layer is likely at a lower temperature irrespective of the pressure used.

Our finding that ulceration with destruction of the muscularis mucosae always occurred when the serosal temperature fell below $-2{ }^{\circ} \mathrm{C}$. is in accord with the findings of Mcllrath et al. (1963) that solid freezing of the gastric wall always resulted in some necrosis of tissue, and of Marx and Kolig (1964) that haemorrhagic necrosis of the mucosa, and sometimes the muscle, invariably followed the recording of a subzero temperature at the serosal surface. The absence of deep muscle damage in four of the five experiments in which the serusal temperature fell below $-4^{\circ} \mathrm{C}$. suggests that the muscle is more resistant to cold than the mucosa. Marx and Kolig (1964) have shown also that acidsecreting gastric mucosa is more sensitive to damage by cold than antral mucosa or oesophageal epithelium.

We conclude from our findings that, if the reactions of the human gastric mucosa to cold are similar to those of the dog, damage to specialized gastric secretory cells by cold is unlikely to be achieved in clinical practice without causing mucosal necrosis.
We thank Dr. A. C. Thackray for his advice and help; Mr. A. C. Catchpole, F.I.A.T., and his colleagues for their help with the experiments; Mrs. I. M. Prentice and Miss J. A. Middleton for the diagrams; and the Photographic Departments at the Middlesex and Central Middlesex Hospitals.

\section{REFERENCES}

Allcock, E. A., Carpenter, A. M., Bernstein, E. F., Peter, E. T., and Wangensteen, O. H. (1963). Structural changes following gastric freezing. Surgery, 53, 764-777.

American Medical Association Survey (1964). Gastric freezing. J. Amer. med. Ass., 187, 1032-1033.

Atik, M., Balart, L. A., Isla, F., and McHardy, G. (1965). Ulceration from gastric freezing. Ibid., 191, 386-388.

Blumgart, L. H., Kay, A. W., Naylor, F. D., and Kugler, J. (1964). Experimental studies with gastric freezing. Gastroenterology, 47, 291-305.

Edwards, D. A. W., Hammond, W. H., Healy, M. J. R., Tanner, J. M., and Whitehouse, R. H. (1955). Design and accuracy of calipers for measuring subcutaneous tissue thickness. Brit. $J$. Nutr., 9, 133-143.

Gilat, T., Clapp, P., Sherlock, P., Creemers, J., Tayao, M. S., Lipkin M., and Almy, T. P. (1964). Effects of freezing on the gastric mucosa of dogs. Gastroenterology, 46, 680-690.

Marx, F. W. Jr., and Kolig, G. (1964). Hemorrhagic necrosis following gastric freezing. Surg. Gynec. Obstet., 119, 1276-1284.

McIlrath, D. C., Hallenbeck, G. A., Allen, H. A., Mann, C. V., Baldes, E. J., Brown, A. L. Jr., and Rovelstad, R. A. (1963). Gastric freezing: an experimental study. Gastroenterology, 45, 374-383.

McSweeney, E. D. Jr., Melnyk, C. S., Deshpande, P. J., Benson, J. A. Jr., and Jacob, S. W. (1963). The supercooled stomach. Surg. Forum, 14, 347-349.

Nachlas, M. M., Tsou, K-C., De Souza, E., Cheng, C-S., and Seligman, A. M. (1957). Cytochemical demonstration of succinic dehydrogenase by the use of a new $p$-nitrophenyl substituted ditetrazole. J. Histochem. Cytochem., 5, 420-436.

Pearse, A. G. E. (1960). Histochemistry-Theoretical and Applied, 2nd ed., pp. 862-882. Churchill, London.

Wangensteen, O. H., Peter, E. T., Nicoloff, D. M., Walder, A. I., Sosin, H., and Bernstein, E. F. (1962). Achieving 'physiological gastrectomy' by gastric freezing. J. Amer. med. Ass., 180, 439-444. 